DOI:10.33766/2524-0323.93.44-52

УДК 342.72/.73(477)

Магновський І. И., доктор юоридичних наук, доиент, професор каредри теорії та філософії права Одеського держаһного університету внутрішніх справ (м. Одеса, Украӥна) e-mail: magn.igor@ukr.net

ORCID iD: http:/ / orcid.org/0000-0001-7336-6212

\title{
ПРАВО ГРОМАДЯН УКРАЇНИ НА ДОСТАТНІЙ ЖИТТЕВИЙ РІВЕНЬ ЯК ОДИН ІЗ КЛЮЧОВИХ ФАКТОРІВ РОЗБУДОВИ СОЩАЛЬНОЇ ДЕРЖАВИ
}

У статті висвітлено в загальнотеоретичному аспекті право громадян України на достатній життевий рівень як одного із ключових факторів розбудови соціальної держави. Визначено проблематику соціального забезпечення громадян на шляху України до побудови громадянського суспільства. Наголошено на соціальній спрямованості сучасної держави через належну соціальну політику, де їі складовою є забезпечення державою соціальних прав осіб, що проживають на їі території.

Означено соціальну сутність держави, яка полягає в здатності забезпечувати задоволення основних потреб усього суспільства в процесі свого функціонування і розвитку.

Указано на вирішальну роль держави в розв'язанні сучасних соціальних проблем від податків і соціальних статей бюджету до контролю за реалізацією соціальних програм.

Ключові слова: Конституція України, права громадян, право на достатній життевий рівень, соціально-економічні права, соціальна держава, механізм забезпечення прав громадян.

Постановка проблеми. 3 огляду на пріоритетність прав людини в процесі розвитку України саме як соціальної держави, про що констатовано в статті 1 Основного Закону держави, сучасний соціально-економічний стан речей та загалом і суспільно-політичний у цілому в краӥні (враховуючи як зовнішні, так і внутрішні негативні чинники) свідчить, на жаль, поки що про декларативний характер цієї основоположної конституційної норми, адже різке соціальне розшарування українського суспільства призвело до проблеми забезпечення такої категорії прав людини, як її право на достатній життевий рівень, про що також зазначено в статті 48 Конституції України [1].

На сьогодні, як констатують науковці, сучасна Українська держава ще не відповідає головним критеріям та загальновизнаним ознакам соціальної держави. Саме тому важливо всебічно дослідити природу соціальної держави в аспекті забезпечення права кожного на достатній життевий рівень як для себе, так і своєї сім'ї [2], тому доцільність та своєчасність розв' язання даної проблематики породжує актуальність ціеї публікації.

Аналіз останніх досліджень і публікацій. Беззаперечно, означеній проблемі певною мірою присвятили свої напрацювання такі науковці, як: К. Г. Волинка, В. О. Демиденко, М. І. Козюбра, М. І. Корнієнко, В. В. Кравченко, А. М. Колодій, В. В. Копєйчиков, О. Г. Кушніренко, С. Л. Лисенков, О. В. Марцеляк, В. В. Мацокін, А. Ю. Олійник, В. Ф. Погорілко, П. М. Рабінович, Т. М. Слінько, Ю. М. Тодика, 
О. Ф. Фрицький, Ю. С. Шемшученко та ряд інших, напрацювання котрих містить корисний за обсягом фактичний матеріал та спонукає до подалыших правових досліджень шляхів утвердження прав і свобод людини.

Формулювання цілей. Метою статті є висвітлення в загальнотеоретичному аспекті права громадян України на достатній життєвий рівень як одного із ключових факторів розбудови соціальної держави.

Виклад основного матеріалу. На думку багатьох учених, у системі прав людини виключно важливе місце посідають саме соціальні права. Вони, з одного боку, покликані гарантувати кожній людині гідні умови життя, а з іншого - визначають обов' язок держави по забезпеченню всіх громадян таким мінімумом соціальних можливостей та соціальної захищеності, які необхідні для підтримки гідності людини, нормального задоволення іiі матеріальних та духовних потреб. Не вирішивши соціальні питання, не можна розраховувати на активну участь індивіда ні в суспільному виробництві, ні в суспільно-політичному житті [3, с. 41].

Найбілыш вагомим міжнародно-правовим актом у сфері закріплення соціальних прав став Міжнародний пакт про економічні, соціальні та культурні права, прийнятий Генеральною Асамблеєю ООН 16 грудня 1966 року. Відповідно до статті 11 Пакту, держави-учасниці визнали:

1) право кожного на достатній життєвий рівень для нього та його сім'ї, що містить достатнє харчування, одежу та житло; а також на безперервне покращення умов життя;

2) держави-учасниці цього Пакту, визнаючи основне право кожної людини на свободу від голоду, повинні вживати необхідних заходів в індивідуальному порядку та в порядку міжнародного співробітництва, у т.ч., і проведення конкретних програм, для того щоб:

а) покращувати методи виробництва, збереження та розподілу продуктів харчування шляхом широкого використання технічних та наукових знань, поширення знань про принципи харчування та удосконалення і реформування аграрних систем таким чином, щоб досягти найбільш ефективного освоєння та використання природних ресурсів;

б) забезпечити справедливий розподіл світових запасів продовольства відповідно до потреб і з врахуванням проблем країн, які як імпортуюють, так і експортуюють харчові продукти [4, с. 128-133].

Право на достатній життєвий рівень передбачено також у ст. 25 Загальної Декларації прав людини: «Кожна людина має право на такий життєвий рівень, включаючи їжу, одяг, житло, медичний догляд та необхідне соціальне обслуговування, який $є$ необхідним для підтримання здоров'я і добробуту їі самої та їі сім'ї, і право на забезпечення в разі безробіття, хвороби, інвалідності, вдівства, старості чи іншого випадку втрати засобів до існування через незалежні від неї обставини» [5, с. 22-23].

Серед усіх соціальних та й конституційних прав і свобод, закріплених розділом II Конституції України, як констатують В. О. Іваненко та В. С. Іваненко, одним із найбільш важливих та соціально значущих для кожної людини є право на достатній життєвий рівень. Ба більше, забезпечення цього права, з одного боку, є метою діяльності кожної демократичної держави, а з другого - одним із основоположних 
принципів сучасної держави. Як зазначають дослідники, «формула забезпечення гідного життя людини» є досить витребуваною в сучасному світі. Вона $є$ і найважливішою конституційною ціллю розвитку багатьох держав, і першою ознакою соціальної держави, і одним з головних передвиборчих політичних лозунгів, і кінцевим завданням соціально-економічних програм уряду, і стрижневою вимогою соціально незахищених верств населення до політичної влади держави, і природною потребою, і суб'єктивним правом кожної особи. Причому, право на достатній життєвий рівень, указують окремі науковці, є базовим для всієї системи соціальних та багатьох економічних прав, оскільки на практищі його реалізація опосередковуєтъся через здійснення саме інших соціальних та майже всіх економічних прав. Навіть білыше, це право випливає із двох фундаментальних правових імперативів іншої групи прав - громадянських прав людини - невід'ємного права кожної людини на життя та права кожного на повагу до його гідності [3, с. 108].

Складність питання про соціально-економічні права в тому, зауважує М. О. Давидова, що їх реалізація залежить від економічних можливостей держави, яка, своєю чергою, перебуває у прямій залежності від ії політики. Ідеться про те, що усунення несправедливості, породжуваної ринком, вирівнювання соціальної нерівності, запровадження соціальних програм можливе за умови втручання держави в ринкові відносини в ім'я соціальної справедливості [6, с. 33].

Усе це зобов' язує державу, наполягає В. І. Гладкіх, відповідним чином регулювати економічні процеси, встановлювати й застосовувати справедливі та ефективні форми перерозподілу суспільного доходу з метою забезпечення добробуту всіх громадян країни. Саме через соціальну політику науковець визначає соціальну спрямованість сучасної держави, як-от: через ії діяльність на досягнення благополуччя суспільства, суспільного прогресу тощо, і ця діяльність знаходить своє вираження у їі сощіальній політищі. Причому, така держава повинна дбати не про свої інтереси, а слугувати суспільству, намагатися звести до мінімуму невиправдані соціальні відмінності [7, с. 5].

П. М. Рабінович та Ю. П. Лобода вважають, що соціальна сутність держави характеризується двома складовими: загально-соціальною (здатність держави задовольняти потреби всього суспільства, передусім забезпечувати його збереження, виживання як цілісного соціального «організму») та спеціально-соціальною (можливість держави задовольняти інтереси насамперед домінуючої, зокрема панівної, частини населення). На їх погляд, загальна характеристика співвідношення двох складових соціальної сутності держави може бути відбита в таких положеннях.

1. Будь-яка держава задовольняє першочергово загальносоціальні потреби та інтереси суспільства, формою політичної організації якого вона виступає.

2. Залежно від конкретних історичних умов держава неодмінно виражає так чи інакше й особливі інтереси певної (домінуючої) частини суспільства, проте лише настільки, наскільки вони, хоч і відрізняються від загальних інтересів суспільства, але не суперечать їм, та все ж не перешкоджають їх задоволенню.

3. Будь-яка держава, як правило, забезпечує у свойй діяльності оптимальне - за даних конкретно-історичних умов - поєднання загальносоціальних інтересів та 
особливих інтересів окремих соціальних спільнот, груп чи осіб; при тому об'єктивним критерієм такої оптимальності якраз і є збереження цілісності та загальної безпеки суспільства як єдиного соціального «організму», який зберігає здатність до самовідтворення й саморозвитку.

4. Тенденцією розвитку держави є поступове усунення (або принаймні послаблення) нею в процесі своєї діяльності протиріч між особливими інтересами та інтересом загальносоціальним. Відтак соціальна сутність держави полягає в здатності держави забезпечувати (у процесі свого функціонування і розвитку) задоволення основних потреб усього суспільства, а також створювати умови для можливого (за наявних конкретно-історичних обставин) задоволення потреб й інтересів окремих груп індивідів та їхніх спільнот [8, с. 41-43].

Як зазначається в науковій літературі, державу можна вважати соціальною, якщо в ній явно і на належному рівні визнані, закріплені та гарантовано забезпечені: соціальна орієнтація економіки, політики, права; основні соціальні права і свободи людини; механізми соціальної солідарності та соціальної справедливості; гідний рівень життя та вільний розвиток людини; заходи щодо запобіганню соціальної нерівності; заходи для «вирівнювання» соціальної нерівності яка виникла; достатній рівень соціальної підтримки, допомоги та захисту людини; спеціальні заходи підтримки соціально незахищених верств суспільства [3, с. 61].

Свого часу відомий український учений-правознавець В. М. Селіванов, ще на початку XX століття, визначив для вчених актуальні задачі, що стояли в той період перед країною, однак залишилися нагальними же й до тепер: а) систематизація наявних концепцій соціальної, правової держави, які висувались в різні історичні періоди, і на цій науково-інформаційній основі розробити методологію дослідження закономірностей становлення функціонування та розвитку демократичної, соціальної та правової держави в Україні; б) проведення дослідження сучасного стану та тенденщій розвитку суспільного ладу та державного устрою України на нових методологічних засадах; в) розробка науково обгрунтованих пропозицій по визначенню завдань та шляхів формування в Україні соціальної, правової держави; г) 3 огляду на статус людини в демократичній, правовій державі, проведення соціальної експертизи відповідності законодавства України про права та свободи людини і громадянина міжнародним стандартам, а також аналіз того, як Україна виконує ратифіковані нею міжнародні норми у сфері захисту прав людини [9, с. 277-278].

Створюючи умови для формування України як правової, соціальної держави, важливо зважати на переконання В. І. Гладкіх про те, що в соціальній державі економіка, політика, ідеологія, законодавство, правозастосовна практика повинні спрямовуватися на створення умов, необхідних для гідного життя і вільного розвитку кожної людини. У такій державі повинні бути закріплені й гарантовані економічні та соціальні права, а також соціальні обов' язки перед суспільством і людиною. На сьогодні особливо актуальною в політико-правовій думщі і на практищі є забезпечення соціальної справедливості. До цього спонукає і значне розшарування населення за прибутками. Тому соціальною можна вважати тільки ту державу, у якій забезпечується сощіальна справедливість, реалізується політика зайнятості, триває процес становлення й розвитку соціально-ринкової економіки, формується гнучка 
система соціального захисту громадян, наявні кроки по забезпеченню соціальної злагоди в суспільстві, створюються умови для зростання соціально-економічної активності громадян та забезпечення достатнього життєвого рівня для кожної людини. Важливо зробити все, щоб соціальна політика Української держави була, 3 одного боку, спрямована на захист соціально незахищених верств населення від жорсткого впливу на них ринкових перетворень, а з іншого, щоб у державі створювалися умови для активізації економічної діяльності різних соціальних груп населення, для їх адаптації до ринкових відносин. Ці завдання соціальної політики на сучасному етапі державотворення є досить складними, а їх реалізація відбувається в непростій економічній та політичній ситуації [7, с. 58-59].

Складовою соціальної політики, указує Б. І. Сташків, є забезпечення державою соціальних прав осіб, що проживають на ії території. Базою для цього є високий рівень економічного розвитку країни, що дозволяє розумно перерозподілити засоби і ресурси, зберігаючи при тому свободу ринкових відносин і підприємництва. Стабільна економіка $є$ реальною гарантією юридичного забезпечення соціальних прав людей. Нестабільна, навпаки, призводить до декларативності закріплених у законах соціальних прав людини [10, с. 68].

Україна має стати саме соціальною державою, оскільки, як слушно зазначає M. В. Тесленко, соціальна держава налаштована на досягнення суспільного блага, яке не можна розуміти як загальну благодійність, що отримує своє вираження в популярному гаслі «рівне рівним». Загальне благо не є сумою окремих частин, це щось принципово єдине, об'єднане принципом взаємної допомоги. Ідеться про стан соціальної справедливості, що випливає з установленого суспільством і законом балансу прав і обов'язків громадян, які одержують можливість рівноправної участі у створенні і поділі загальної міри суспільного добробуту. Тобто соціальна держава не створює, а тільки визначає природні й особисті права громадян, надаючи при тому для них можливість розвиватися і діяти відповідно до власних бажань, особистих інтересів [11, с. 41].

Н. В. Путило, як цілі соціальних прав у сучасному суспільстві, розглядає закріплення обов'язку суспільства сприяти досягненню гідного рівня життя кожного свого члена з допомогою потенщіалу державних інститутів. Будучи свого роду претензіями до суспільства, соціальні права покликані компенсувати всі ті негативні наслідки соціальних хвороб, які позбавляють особу доступності елементарних благ [12].

Погоджуючись із М. В. Баглаєм, зауважимо, соціальна держава покликана створювати необхідні умови для забезпечення громадян роботою, охороняти працю, перерозподіляти доходи через державний бюджет, забезпечувати прожитковий мінімум, сприяти розвитку підприємнищтва, турбуватися про освіту, культуру, сім'ю, охорону здоров' я, соціальне забезпечення тощо. З’ ясувалося, зазначає він, що, окрім, власне, соціальної політики, соціальної орієнтації має набути вся економічна політика держави, культура, право; держава має заохочувати ініціативу, конкуренщію та економічну свободу, інтерес до зростання особистого доб- 
робуту. Держава повинна боротись не проти багатства, а проти злиднів, не допускати надмірної доброчинності та заохочувати соціальні функції приватної власності [13, с. 119].

Соціальна складова механізму забезпечення права громадян України на достатній життевий рівень обумовлена тим, зауважує Т. В. Семигіна, що будь-яка держава (навіть економічно розвинена) змушена періодично змінювати або ж корегувати власну модель соціальної політики [14, с. 135].

В. О. Іваненко та В. С. Іваненко одностайні в тому, що роль держави та ії органів у вирішенні соціальних задач в усіх сучасних країнах, навіть із дуже розвиненими інститутами «соціальної держави» « «ромадянського суспільства», $\epsilon$ (i в майбутньому залишатиметься) вирішальною - від податків і соціальних статей бюджету до контролю за реалізацією соціальних програм [3, с. 53].

При тому, головна увага держави, зазначає Б. І. Сташків, має бути зосереджена на наданні допомоги тим, хто сам не може забезпечити собі належний життевий рівень, як правило, з об'єктивних причин, наприклад, у разі виникнення так званих складних життевих обставин. Під останніми, зазвичай, розуміють ті обставини, що «об'єктивно порушують нормальну життедіяльність особи, наслідки яких вона не може подолати самостійно. Найчастіше останніми є інвалідність, часткова втрата рухомої активності через старість або стан здоров'я, самотність, сирітство, безпритульність, відсутність житла чи роботи, насильство, зневажливе ставлення та негативні стосунки в сім'ї, малозабезпеченість, психологічний або психічний розлад, стихійне лихо, катастрофа [10, с. 77].

Висновки. Таким чином, зазначене вище свідчить про необхідність розроблення та запровадження на основі концептуальних засад відповідного дієвого механізму соціального регулювання на національному рівні, із юридичним наповненням його змісту та чітко визначеними складовими чинниками нормативноправового та організаційно-інституційного характеру, а також його запровадження у фактичну дійсність, із належним коригуванням у процесі свого функціонування щодо задоволення основних потреб усього суспільства загалом та забезпечення права громадян України на достатній життевий рівень зокрема.

\section{Використані джерела:}

1. Конституція України. Науково-практичний коментар / редкол.: В. Я. Тацій (голова редкол.), О. В. Петришин (відп. секретар), Ю. Г. Барабаш та ін. ; Нац. акад. прав. наук України. 2-ге вид., переробл. і допов. Харків : Право, 2011. 1128 с.

2. Мацокін В. В. Право громадян Украӥни на достатній життевий рівень : автореф. дис. ... канд. юрид. наук : 12.00.02. Національна юридична академії України імені Ярослава Мудрого. Харків, 2008.19 с.

3. Иваненко В. А., Иваненко В. С. Социальные права человека и социальные обя занности государства: международные и конституционные правовые аспекты. СанктПетербург : Юридический центр Пресс, 2003. 404 с.

4. Международные акты о правах человека: сб. документов / сост. В. А. Карташкин. Москва : НОРМА, 2002.789 c.

5. Права людини. Міжнародні договори Украӥни, декларащії, документи / упоряд. Ю. К. Качуренко. Київ : Наук. думка, 1992. 200 с. 
6. Давидова М. Соціально-економічні права як критерій аналізу і класифікації сучасних демократичних держав. Право Украӥни. 2001. № 8. С. 32-35.

7. Гладкіх В. Соціальні права громадян в аспекті формування України як соціальної, правової держави. Право Украӥни. 2005. № 10. С. 57-60.

8. Рабінович П., Лобода Ю. Соціальна сутність держави: теоретико-методологічні засади дослідження. Право України. 2001. № 8. С. 41-44.

9. Селіванов В. М. Право і влада суверенної України : методологічні аспекти. Київ : Вид. Дім «ннЮре», 2002. 724 с.

10. Сташків Б. Функції права соціального забезпечення. Право Украйни. 2001. № 7. C. 66-69.

11. Тесленко М.В. Право як інструмент соціальної справедливості. Право Украӥни. 2004. № 7. C. 40-43.

12. Путило Н. Основы правового регулирования социальных прав : автореф. дис. ... канд. юрид. наук : 12.00.01. Институт законодательства и сравнительного правоведения при Правительстве Российской Федерации. Москва, 1999. 20 с.

13. Баглай М.В. Конституционное право Российской Федерации. Москва : НОРМА, 2002. 684 c.

14. Семигіна Т. Традиційні моделі соціальної політики в умовах глобалізації. Людина і політика. 2004. № 1. С. 134-143.

\section{References:}

1. Konstytutsiia Ukrainy. Naukovo-praktychnyi komentar. (2011) V. Ya. Tatsii (Ed.) O. V. Petryshyn, \& Yu. H. Barabash et al. ; Nats. akad. prav. nauk Ukrainy. 2-he vyd., pererobl. i dopov. Kharkiv: Pravo. [in Ukrainian].

2. Matsokin, V. V. (2008) Pravo hromadian Ukrainy na dostatnii zhyttievyi riven. Extended abstract of candidate's thetsis. Natsionalna yurydychna akademii Ukrainy imeni Yaroslava Mud roho. Kharkiv. [in Ukrainian].

3. Ivanenko, V. A., Ivanenko, V. S. (2003) Socialnye prava cheloveka i socialnye obyaza nnosti gosudarstva: mezhdunarodnye i konstitucionnye pravovye aspekty. Sankt-Peter burg : Yuridicheskij centr Press. [in Ukrainian].

4. Mezhdunarodnыe akty o pravakh cheloveka: sb. dokumentov. (2002) V. A. Kartashkyn (Ed.). Moskva : NORMA. [in Ukrainian].

5. Prava liudyny. Mizhnarodni dohovory Ukrainy, deklaratsii, dokumenty. (1992) Yu. K. Kachurenko (Ed.). Kyiv : Nauk. dumka. [in Ukrainian].

6. Davydova, M. (2001) Sotsialno-ekonomichni prava yak kryterii analizu i klasyfikatsii suchasnykh demokratychnykh derzhav. Pravo Ukrainy - Law of Ukraine, 8, 32-35. [in Ukrainian].

7. Hladkikh, V. (2005) Sotsialni prava hromadian v aspekti formuvannia Ukrainy yak sotsialnoi, pravovoi derzhavy. Pravo Ukrainy-Law of Ukraine, 10, 57-60. [in Ukrainian].

8. Rabinovych, P., Loboda, Yu. (2001) Sotsialna sutnist derzhavy: teoretyko-metodolohichni zasady doslidzhennia. Pravo Ukrainy - Law of Ukraine, 8, 41-44. [in Ukrainian].

9. Selivanov, V. M. (2002) Pravo i vlada suverennoi Ukrainy: metodolohichni aspekty. Kyiv : Vyd. Dim «InIure». [in Ukrainian].

10. Stashkiv, B. Funktsii prava sotsialnoho zabezpechennia. Pravo Ukrainy - Law of Ukraine, 7, 66-69. [in Ukrainian].

11. Teslenko, M. V.(2004) Pravo yak instrument sotsialnoi spravedlyvosti. Pravo Ukrainy Law of Ukraine, 7, 40-43. [in Ukrainian]. 
12. Putilo, N. (1999) Osnovy pravovogo regulirovaniya socialnyh prav. . Extended abstract of candidate's thetsis. Institut zakonodatelstva i sravnitelnogo pravovedeniya pri Pravitelstve Rossijskoj Federacii. Moskva. [in Ukrainian].

13. Baglaj, M. V. (2002) Konstitucionnoe pravo Rossijskoj Federacii. Moskva : NORMA, 2002. 684 c. [in Ukrainian].

14. Semyhina, T. (2004) Tradytsiini modeli sotsialnoi polityky v umovakh hlobalizatsii. Liudyna i polityka - Man and politics, 1, 134-143. [in Ukrainian].

Стаття надіӥшла до редколегї 15.01.2021

Магновский И. И., доктор юридических наук, доцент, профессор кафедры теории и философии права Одесского государственного университета внутренних дел (2. Одесса, Украина)

\section{ПРАВО ГРАЖДАН УКРАИНЫ НА ДОСТАТОЧНЫЙ ЖИЗНЕННЫЙ УРОВЕНЬ КАК ОДИН ИЗ КЛЮЧЕВЫХ ФАКТОРОВ РАЗВИТИЯ СОЦИАЛЬНОГО ГОСУДАРСТВА}

В статье освещены в общетеоретическом аспекте право граждан Украины на достаточный жизненный уровень как один из ключевых факторов развития социального государства. Определена проблематика социального обеспечения граждан на пути Украины к построению гражданского общества.

Отмечена социальная направленность современного государства через надлежащую социальную политику, где её составляющей является обеспечение государством социальных прав лищ, проживающих на её территории.

Выделена социальная сущность государства, которая заключается в способности обеспечивать в процессе своего функционирования и развития удовлетворение основных потребностей всего общества. Указано на решающую роль государства и его органов в решении социальных задач во всех современных странах - от налогов и социальных статей бюджета до контроля за реализацией социальных программ.

Ключевые слова: Конституция Украины, права граждан, право на достаточный жизненный уровень, социально-экономические права, социальное государство, механизм обеспечения прав граждан.

Mahnovskyi I., Doctor of Law, Associate Professor, Professor of the Department of theory and philosophy of Law faculty of experts training for pre-trial investigation bodies Odesa State University of Internal Affairs (Odesa, Ukraine)

\section{THE RIGHT OF CITIZENS OF UKRAINE TO A SUFFICIENT LIVING STANDART AS ONE OF THE KEY FACTORS OF THE SOCIAL STATE DEVELOPMENT}

The article covers in general theoretical terms the right of citizens of Ukraine to a sufficient standard of living as one of the key factors in building a welfare state. The place of social rights in the human rights system is indicated, which, on the one hand, are designed to guarantee decent living conditions for everyone, and on the other - determine the obligation of the state to provide all those in need with the minimum social opportunities and 
social protection. normal satisfaction of his material and spiritual needs. The issue of social security of citizens on the way of Ukraine to building a civil society is identified. Emphasis is placed on the social orientation of the modern state through a proper social policy where its component is to ensure the state of social rights of persons living in its territory, through social responsibilities to society and man. The social essence of the state is defined, which consists in ability to provide, in the course of the functioning and development, satisfaction of the basic needs of all society in which there is a process of formation and development of social market economy, the flexible system of social protection of citizens is formed. society, conditions are created for the growth of socio-economic activity of citizens. When creating conditions for the formation of Ukraine as a legal, social state, it is important to take into account that the economy, politics, ideology, legislation, law enforcement practice should be aimed at creating the conditions necessary for a dignified life and free development of everyone. It is emphasized that in the welfare state the following are clearly and at the appropriate level recognized, fixed and guaranteed: social orientation of economy, politics, rights; basic social rights and human freedoms; mechanisms of social solidarity and social justice; decent standard of living and free human development; measures to prevent social inequality; measures to «equalize» the resulting social inequality; sufficient level of social support, assistance and human protection; special measures to support socially vulnerable segments of society. The crucial role of the state and its bodies in solving social problems in all modern countries - from taxes and social budget items to control over the implementation of social programs. It is stated that the right to an adequate standard of living is basic for the whole system of social and many economic rights, because in practice its implementation is mediated through the exercise of other social and almost all economic rights.

Keywords: Constitution of Ukraine, citizens' rights, right to a sufficient standard of living, socio-economic rights, welfare state, mechanism for ensuring citizens' rights.

\section{DOI:10.33766/2524-0323.93.52-61 УДК 343.9:342.56}

Малетов Д. В., аспірант кафедри адміністративного, господарського права та фінансово-економічної безпеки Навчально-наукового інституту права Сумського державного університету (м. Суми, Украӥна)

e-mail: d.maletov@yur.sumdu.edu.ua

ORCID iD: http:/ / orcid.org/0000-0002-1241-1005

\section{ЩОДО ПИТАННЯ ПРОФЕСІЙНОЇ ПІДГОТОВКИ СУДДІВ ВИЩОГО АНТИКОРУПЦЙНОГО СУДУ УКРАЇНИ}

У статті визначено, що професійна підготовка судді $є$ грунтовною базою для забезпечення якісної роботи системи правосуддя. Доведено, що безперервність підвищення кваліфікації суддів зумовлена динамічністю правовідносин.

Автором встановлено, що особливостями навчання суддів Вищого антикорупщійного суду є наявність в законі додаткових гарантій підвищення їхньої професійної підготовки та проведення їі з дотриманням принципу спеціалізації.

Ключові слова: професійна підготовка суддів, навчання суддів, підвищення кваліфікації суддів, антикорупщійний суд України.

(C) Малетов Д. В., 2021 